Article

\title{
Social Stratification of Education by Ethnic Minority Groups over Generations in the UK
}

\author{
Laurence Lessard-Phillips ${ }^{1, *}$ and Yaojun $\mathrm{Li}^{2,3}$ \\ ${ }^{1}$ Institute for Research into Superdiversity, School of Social Policy, University of Birmingham, Birmingham, B15 2TT, UK; \\ E-Mail: I.lessard-phillips@bham.ac.uk \\ 2 Department of Sociology, University of Manchester, Manchester, M13 9PL, UK; E-Mail: yaojun.li@manchester.ac.uk \\ ${ }^{3}$ Cathie Marsh Institute for Social Research, University of Manchester, Manchester, M13 9PL, UK \\ * Corresponding author
}

Submitted: 14 October 2016 | Accepted: 12 January 2017 | Published: 28 March 2017

\begin{abstract}
A large body of research has been conducted both on the social stratification of education at the general level and on the educational attainments of ethnic minority groups in the UK. The former has established the increasing fluidity in the class-education association, without paying much attention to ethnicity, whilst the latter has shown reinvigorated aspirations by the second generation without fine-grained analyses. This paper adds to this literature by examining the relationship between family class, ethno-generational status and educational attainment for various $1^{\text {st }}, 1.5,2^{\text {nd }}, 2.5,3^{\text {rd }}$ and $4^{\text {th }}$ generations in contemporary UK society. Using data from Understanding Society, we study the educational attainment of different ethno-generational groups. Our analysis shows high educational selectivity among the earlier generations, a disruptive process for the 1.5 generation, high second-generation achievement, and a 'convergence toward the mean' for later generations. Parental class generally operates in a similar way for the ethno-generational groups and for the majority population, yet some minority ethnic groups of salariat origins do not benefit from parental advantages as easily. An 'elite, middle and lower' structure manifests itself in the intergenerational transmission of advantage in educational attainment. This paper thus reveals new features of class-ethno relations hitherto unavailable in UK research.
\end{abstract}

\section{Keywords}

class; educational attainment; ethnicity; minorities; multiple-generation groups; social stratification; UK

\section{Issue}

This article is part of the issue "International Migration and Ethnic Integration", edited by Yaojun Li (University of Manchester, UK) and Anthony Heath (University of Oxford, UK).

(C) 2017 by the authors; licensee Cogitatio (Lisbon, Portugal). This article is licensed under a Creative Commons Attribution 4.0 International License (CC BY).

\section{Introduction}

The national origins of ethnic minority groups to Britain have changed in recent decades. While Britain has had a very long history of immigration, most of the main visible ethnic minority groups came after the end of the Second World War via post-colonial, economic, asylum, or family reunification routes. For instance, members of the black Caribbean group mostly came from Jamaican islands in the 1950s and 1960s, Indians from India and Africa in the 1960s and 1970s, Pakistanis and Bangladeshis in the 1970s and 1980s, and black Africans in the 1980s and 1990s. Of course, many members of visible and nonvisible ethnic minority origins such as Chinese and Eastern and Western Europeans did not come in groups in the same manner as the (mostly) post-colonial groups above, but individually, later joined by families. Some of these groups have been in the country for a very long time (Castles \& Miller, 2009; Cheng, 1994; Cheung \& Heath, 2007; Lessard-Phillips, Fleischmann, \& van Elsas, 2014; Li \& Heath, 2016). A considerable proportion of the visible minorities came at a quite young age, and a signifi- 
cant and a growing portion were born in the country, being second or even third generation at the current time (see Lessard-Phillips, Galandini, de Valk, \& Fibbi, 2015, for details on the terminology). The share of ethnic minority groups in Britain has thus increased from $2.9 \%$ in 1951 (Cheung \& Heath, 2007, p. 512) to 14\% in 2011 (Office for National Statistics, 2012) and has been predicted to grow to approximately 20-30\% over the next few decades (Lievesley, 2010; Rees, Wohland, Norman, \& Boden, 2012). Those born in Britain or those who arrived at a young age will have received their schooling in Britain and have entered the labour market with British qualifications. The extent to which they fare well in the educational and occupational structures, as an integral part of socio-economic integration, has been a major concern of academic and policy research.

The inclusion of ethnic minority groups in British society, including both the migrant generation and their descendants who grew up in the country is, as Li and Heath (2016) commented, at the forefront of current policy debates, despite the lack of clear policies attempting to tackle the issue. Recent British governments have placed an emphasis on integration as an important societal goal (e.g. Department for Communities and Local Government, 2012; Casey, 2016), and the current government has set up a 'Race Disparity Unit' under the Cabinet Office to try to gauge ethnic disadvantages in education and in the labour market. However, such programmes tend to focus on piece-meal responses to local issues rather than implementing relevant policies (Hepburn, 2015). For instance, the centralist New Labour government put much emphasis on 'Education, Education and Education' but failed to tackle the underlying class difference in educational stratification (Goldthorpe, 2010). It is also apt to point out that race and ethnic issues remained largely out of the 'Middle England' political orientation. The coalition and Conservative governments claimed to place their priorities on the promotion of social mobility (Cabinet Office, 2011; Civil Service, 2016) and social justice (Department for Work and Pensions, 2012), but the strategies largely failed to engage with the particular challenges faced by marginalised groups, especially those from ethnic minority backgrounds. Without effective evidence-based policy interventions, the potential for marginalised groups to improve their mobility and integration chances is likely to be limited.

In this paper, we aim to provide evidence on the educational attainment of ethno-generational groups in Britain. In order to do this, we followed and developed the novel approach by Li and Heath (2016) in combining the stratification and ethnic studies traditions and, furthermore, making a more refined differentiation of ethno-generation groupings than found in any existing studies in the UK. In so doing, we seek to determine the socio-ethno-generational factors underlying educational attainment. Our results suggest a complicated story of immigrant advantage and a 'regression to the mean' for later generations. Our approach brings greater com- plexity to analysis on education and highlights the need to consider the diversity of origin and the multiplicity of generation along with family class in investigating educational stratification as a means of promoting social inclusion.

\section{Educational Attainment: Bridging Stratification and Assimilation}

Education is one of the most important components of human and cultural capital (Becker, 1962; Bourdieu, 1986) and its importance for the labour market position just as for other domains of people's socio-economic life is undisputed. Social scientists, sociologists in particular, have long been concerned with the unequal opportunities in educational attainment. Yet, there has been a sort of 'division of labour' on educational analysis, with the mainstream sociologists focusing on family class differences and ethnic studies scholars on ethnic differences in educational attainment (Li \& Heath, 2016). Part of this divide is due to disciplinary traditions and part due to data limitations. Prominent mobility scholars have conducted studies on the class-educational association (Bukodi, Erikson, \& Goldthorpe, 2014; Devine \& Li, 2013; Halsey, Heath, \& Ridge, 1980; Paterson \& Iannelli, 2007) but ethnicity rarely enters the picture. Attention is focused on class gradients or on the extent and direction of possible changes in social fluidity in education (Breen, Luijkx, Müller, \& Pollak, 2009). Early students of migration and ethnicity, on the other hand, have been concerned with the ethnic disadvantages in education rather than with family class effects (Bhattacharyya, Ison, \& Blair, 2003; Connor, Tyers, Modood, \& Hillage, 2004; Dale, Shaheen, Kalra, \& Fieldhouse, 2002; Drew, Gray, \& Sporton, 1997; Heath \& McMahon, 1997), but this is changing (Jackson, 2012; Lenkeit, Caro, \& Strand, 2015; Rothon, 2007).

From the point of view of mainstream stratification research, the primary concern is how origin class uses its superior socio-economic-cultural resources to help the educational attainment of their children, how social inequality is maintained over time and across countries, and whether or to what extent this rigidity is being loosened (Breen \& Jonsson, 2005; Breen et al., 2009). If we think about the Origin-Education-Destination (OED) model of status attainment (Blau \& Duncan, 1967; Sewell, Haller, \& Portes, 1969), the focus is on the relationship between parental social origins and education, and the ways in which class-origin advantages are transmitted in the educational realm. Among the ways in which these advantages are transmitted, the focus is on social capital (Coleman, 1988), cultural capital (DiMaggio, 1982) and economic capital (Breen \& Goldthorpe, 1999). Within this stream of research, there is no reason why origin class would function in different ways for different ethnogenerational groups, and ethnicity is thus rarely acknowledged within social stratification research on education even though class may work differently for different eth- 
nic groups (Platt, 2016). There have also been recent attempts to add migrant/ethnic status to the OED model (see, e.g., Heath et al., 2008; Li \& Heath, 2016; Zuccotti, 2015), but research is still in its infancy.

From the ethnic studies perspectives, a long-held view foresees a gradual process of ethnic convergence across generations. The revised straight-line assimilation theory, as espoused by Alba and his colleagues (Alba, Lutz, \& Vesselinov, 2001; Alba \& Nee, 2003; Waters, Tran, Kasinitz, \& Mollenkopf, 2010) and reformulated from the classical assimilation theory developed by the founders of the Chicago School of Sociology, predicts a 'process of interpenetration and fusion' of early 20th-century migrants with the host society (Park \& Burgess, 1921, p. 735). The defining features of the process include the successive generational upward mobility, greater integration into the mainstream, and reduced ethnic distinctiveness in terms of language use, residential concentration and marriage patterns for most minority ethnic groups (Gordon, 1964). The most important implication of this revised theory for our present purposes is that, overall, the second and higher generations can be expected to make educational progress which will facilitate increasing integration into the host society's socioeconomic life. But origin class effects are overlooked in this account. In this latter regard, we need to note that the 'segmented assimilation theory' proposed by Portes and colleagues (Portes, Fernández-Kelly, \& Haller, 2009) does acknowledge the role of parent class but only suggests a binary structure.

The foregoing discussion has suggested that as the proportion of ethnic minority groups in the UK has increased with many being second and higher generations, the educational disparities with the mainstream population may have reduced. Recent research shows that ethnic minority members tend to do well and some groups even outperform the majority group in education (Demack, Drew, \& Grimsley, 2000; Dustmann \& Theodoropoulos, 2010; Heath, Rothon, \& Kilpi, 2008; Jackson, 2012; Rothon, Heath, \& Lessard-Phillips, 2009; Strand, 2014). Yet there are various unsolved issues in existing research. Firstly, the distinction between ethnicity and generation is not explicitly made and research on third generation education has not been possible due to data limitations. Secondly, we do not know whether the possible increasing fluidity in the class-education association in Britain is due to narrowing class inequality as suggested by Breen et al. (2009) or to increasing ethnic outperformance over whites in spite of their lower parental class positions. By combining the stratification and the ethnic studies traditions could thus not only shed light on the apparent mystery in Breen et al.'s findings but also help us gain a deeper understanding of the class-education associations over different generations of ethnic groups in Britain. It could help test whether the revised assimilation theory could find its support in the British context.

With these considerations in mind, we aim to address the following questions:
- Do the minority ethnic groups over different generations in the UK have the same level of educational attainment as their White British peers without an immigration background?

- Are patterns of ethnic overperformance found in the existing literature supported when a more granular measure of ethno-generational status is used?

- Is social advantage and disadvantage (SAD) transmitted in the same way for minority ethnic groups as for the majority group?

Answering those questions will help further our understanding of the education of ethno-generational groups in Britain and provide a strong evidence base for studying the educational mobility of ethnic groups across generations.

\section{Data and Methods}

We use the first three waves of the United Kingdom Household Longitudinal Survey, also called Understanding Society (USoc; University of Essex, Institute for Social and Economic Research, \& National Centre for Social Research, 2013) for this study. We pooled them together to maximise sample size. Our analytical sample size $(N=37,846)$ includes individuals with valid values on all variables used in the analysis. The USoc has ethnic boost samples and contains information about grandparental, parental, and respondent's place of birth which, given its large sample size, allowing us to differentiate 48 ethno-generational groupings with sufficient sample sizes for analysis (see note 2 of Table 1). This is more refined than any existing research in the UK has attempted. We were able to differentiate, whenever possible, between individuals from the first generation (individuals born outside of the UK and who arrived to the UK after age 16); the 1.5 generation (individuals arriving to the UK during compulsory schooling-ages 6 to 16); the second generation (individuals born in the UK of nonUK born parents or who migrated before age 6); the 2.5 generation (individuals with one immigrant and one UK-born parent); the third generation (individuals born in the UK with at least one non-UK-born grandparent); and the fourth generation (individuals born in the UK with UK-born parents and UK-born grandparents). We were also able to differentiate between many of the ethnic groups usually found in British survey data. This allowed us to have fine-grained ethno-generational categories that also take into account immigrant parentage for the white groups, something not often found in research but nonetheless important given historical migratory flows to the UK from neighbouring or Old Commonwealth countries. Ethnicity is based on ethnic selfclassification, a measure that is subjective and a changeable over one's life course (Simpson, Warren, \& Jivraj, 2015) and may imply a mismatch between reported and externally perceived ethnicity. We focussed our analyses 
Table 1. Ethnicity by generational status in Britain, respondents aged 25-64 (2009-2012).

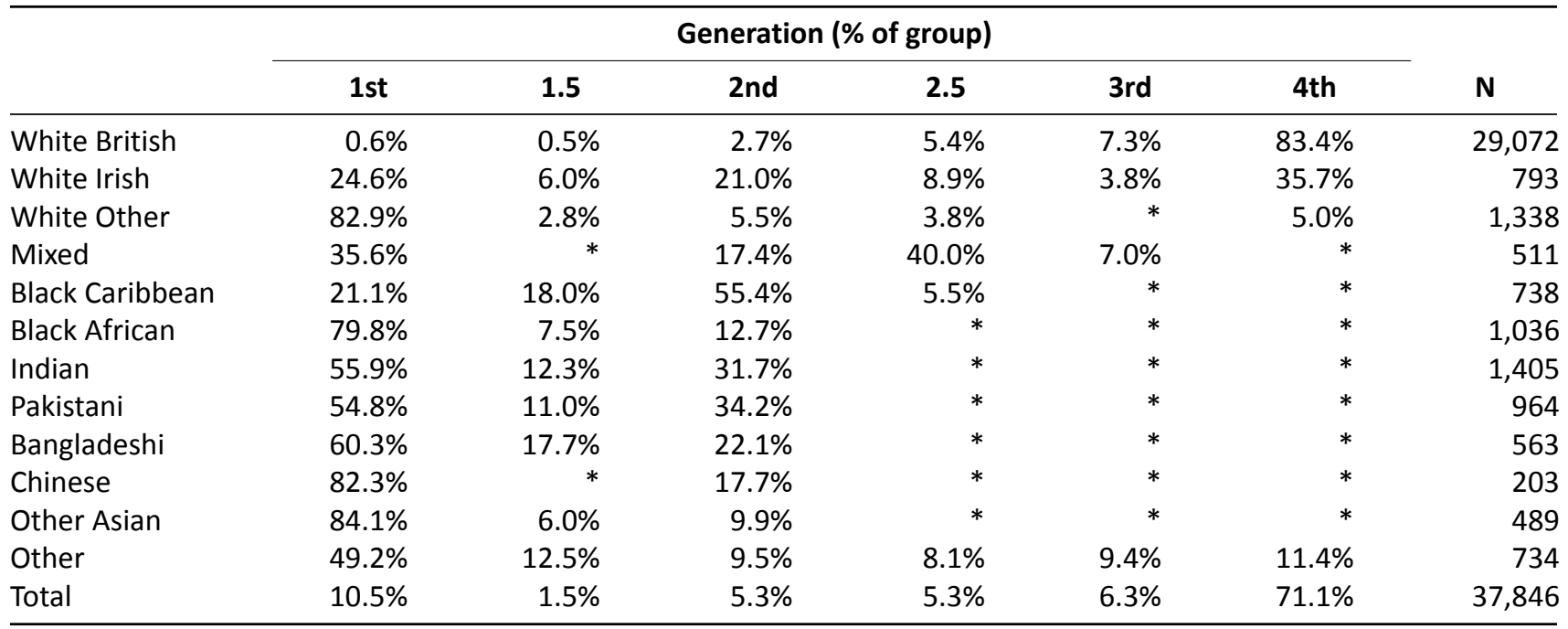

Notes: 1. Weighted analysis and unweighted Ns (authors' analysis). Row totals may not add to $100 \%$ due to rounding errors;

2. Cell counts under 30 are considered too small for analysis and merged with the 'Other group'. Source: Understanding Society.

on respondents aged 25-64. As we can see from Table 1, there is quite a variation in the generational status distribution among the various ethnic groups, which tend to follow the migratory patterns of the different groups (Lessard-Phillips et al., 2014).

We investigated the patterns and trends of educational attainment in the UK by different ethnogenerational groups in the following way. We constructed a measure of parental class by deriving the 3class version of the National Statistics Socio-Economic Classification (NS-SEC) from the 2010 Standard Occupational Classification (SOC2010) of parental occupation when respondents were 14 years of age. Using the dominance approach, which will often use the occupation of the non-immigrant parent in the 2.5 generation, the three-fold parental class schema covers (1) professional/managerial salariat (I-II), (2) intermediate class (IIIIV), and (3) manual working class (semi-routine, routine, V-VII). With regard to education, and given the importance of university-level education for gaining high-level occupations and for fostering social mobility (Garratt \& $\mathrm{Li}, 2005)$, we looked at the respondents' highest level of educational attainment and differentiate between those with degree-level or above qualifications and those without. We also used indicators of age and sex of the respondents (the descriptive statistics of age, sex and parental class are shown in Table 2). In the analyses, we first look at descriptive statistics to examine gross differentials. We then use a logit model of degree-level attainment for the full sample, comparing each of the ethnogenerational status groups with the 4th generation white British (our reference category), to investigate ethnic differentials in educational attainment. Our models include parental class as the main explanatory variable and controls for age and sex. As the logits (log odds ratios) from the models are less intuitive to understand, we present average marginal effects (Mood, 2010).
Table 2. Main control variables and their distribution in the data.

\begin{tabular}{ll}
\hline Age & \\
Mean & 44.4 \\
SE & 0.09 \\
Range & $25-64$ \\
\hline Sex (\%) & \\
Men & 49.1 \\
Women & 50.1 \\
\hline Highest parental class (\%) & 33.3 \\
Professional/managerial: salariat & 27.7 \\
Intermediate class & 39.0 \\
Manual working class (semi-routine, routine) & 37,846 \\
\hline $\mathrm{N}$ & \\
\hline Source: Understanding Society.
\end{tabular}

\section{Results}

Figure 1 portrays the percentage of university degree holders among the various ethnic groups by generational status.

Before we enter detailed discussion, we alert readers that unlike bar charts we usually see in academic papers, the bars in Figure 1 do not add to one hundred percent. Rather, for each of twelve ethnic minority groups, we have 'stacked' the percentages of respondents in each generational status who have degree-level education or above. For large ethnic groups such as white British, we could differentiate six generational statuses $\left(1^{\text {st }}, 1.5,2^{\text {nd }}\right.$, $2.5,3^{\text {rd }}$ and $4^{\text {th }}$ generations) whereas for small ethnic groups such as Chinese, we could only differentiate two generational statuses $\left(1^{\text {st }}\right.$ and $\left.2^{\text {nd }}\right)$. The $4^{\text {th }}$ generation white British comprise the largest majority of all groups 


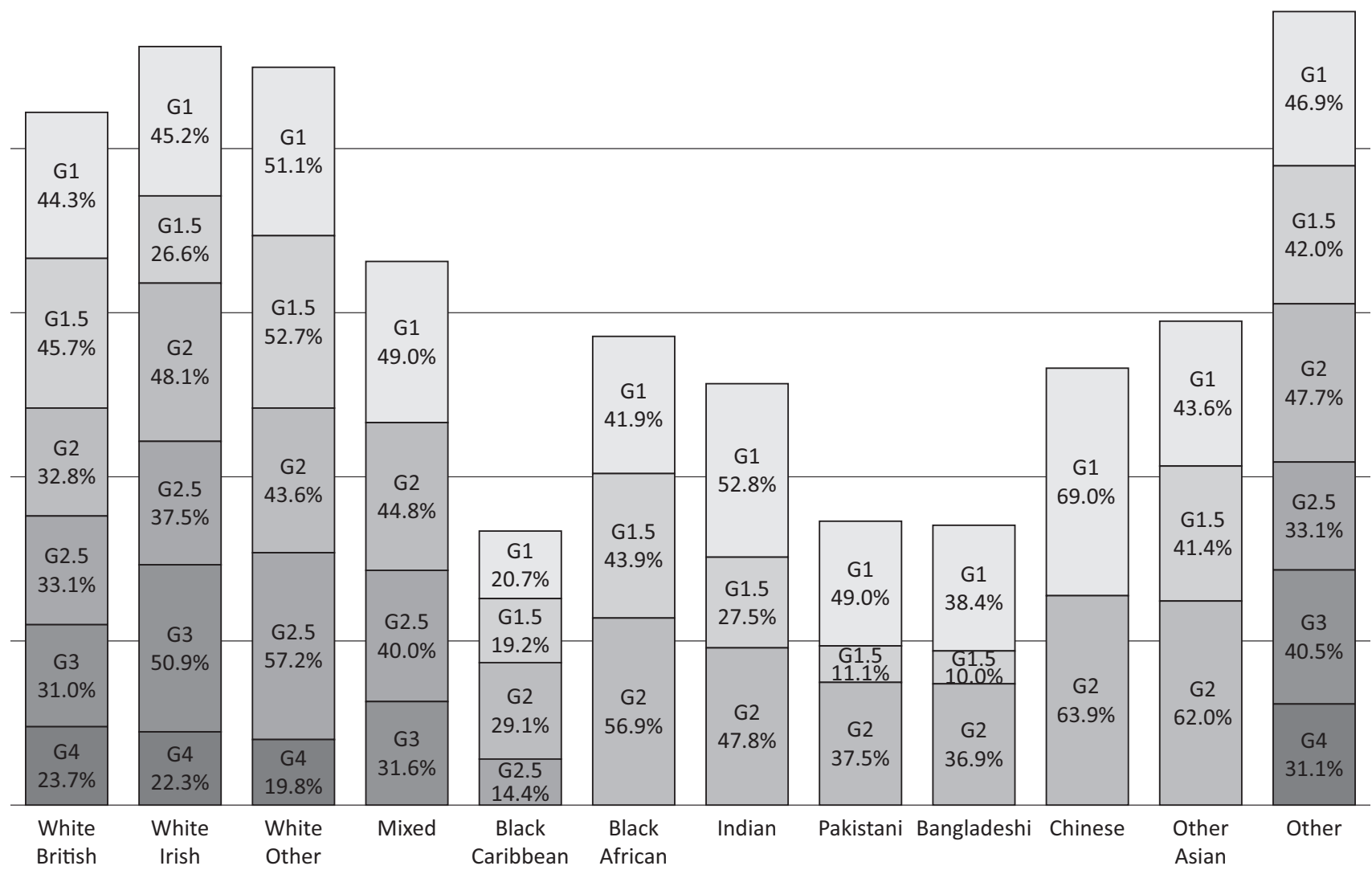

Figure 1. Degree-level attainment by ethno-generational status. Source: Understanding Society.

in our data. As such, they constitute the 'core' of the population and serve as the meaningful reference group for all other groupings.

Looking in closer detail at the patterns in Figure 1, we find features which tend to go unnoticeable in standard ethnic studies due to the crude measures of ethnogenerational groups but which are brought into great relief thanks to our refined measurement. Firstly, we find clear evidence of first-generation positive selection for white groupings and for most of the visible ethnic minority groups alike, rendering support to claims by Borjas (1987) in the American context and to Li and Heath (2016) on the selection effects on ethnic social mobility. Thus, white British, white Irish (those from the Republic of Ireland), white Other (from North America, Western Europe, Australia and New Zealand, and Central and Eastern Europe), mixed (namely, white and black, white and Asian), Black African, Indian, Pakistani, Bangladeshi, Chinese, Other Asian, and 'Other' respondents of the migration generation are all highly educated, with two thirds of Chinese and over half of Indian first-generation respondents having degree level education or above. This forms a very sharp contrast to the $23.7 \%$ for the white British mainstream (fourth generation) with university education.

The first generation ethnic minority groups, in spite of their high level of education, tend to face great difficulties in the British labour market as their qualifications were obtained overseas and are not usually seen as hav- ing the same 'values' by employers. Thus, they tend to face higher levels of unemployment or find themselves in menial jobs (Heath \& Li, 2008; Li, 2010). One of the possible implications is that those arriving in the young ages may, given the precarious employment position of their parents and financial difficulties in their families, opt for the labour market rather than continuing education at the end of compulsory schooling. Thus, we find that the 1.5 generation respondents of black Caribbean, Pakistani, and Bangladeshi heritages are all less likely to have degree level education than either their $1^{\text {st }}$ or $2^{\text {nd }}$ generation peers. This notwithstanding, it is also the case that other 1.5 generation respondents are not less likely to have degree levels than their 4th generation white British peers and this may indicate a pattern of additional investment to avoid hardship or discrimination on the labour market (Heath et al., 2008).

Thirdly, we find a quite consistent pattern of secondgeneration advantage among most groups (as compared to the $4^{\text {th }}$ generation white British) that also applies to members of the 2.5 and $3^{\text {rd }}$ generations, with very few exceptions. There also seems to be a clear case of 'regression to the mean' with regard to more established generations in the white groups. For these groups, the percentages with degree level qualifications decline over generations towards that of 4th generation white British, our core group (although some may be due to the younger age profile of some of these groups). This is a sign of 'inte- 
gration' although it speaks of ethno-generational groups losing the competitive edge in education. We are unable to look into this issue further for ethnic minority groups because of sample size issues, but if their skin colour remains an inhibiting factor in employment and career advancement, this kind of integration could work to the disadvantage of visible ethnic minority groups.

The patterns highlighted above could be due to many factors, including selectivity and generational change in overall levels of education or different ages or historical times of arrival with different educational opportunities open to them, resulting in group-specific attainment profiles. But we also need to look at the profile from a class perspective. The data are shown in Figure 2, which depicts the distribution of degree qualifications by parental class and ethnic group. The patterns here are more in line with a narrative of higher educational attainment among higher parental social classes. This appears to hold for all ethnic groups, with the sole exception of black Caribbean respondents in the salariat. There are, however, some groups where the percentage of degree holders is much higher than for the White British across all socio-economic categories. This is especially the case for the Chinese and Indian groups. It is also worth noting that among those from working-class families, all other ethnic groups are more likely than the white British to have degrees, with the Chinese four times as likely (46.0\% and $12.1 \%$ respectively). Thus, at least at prima facie level, class does not work in the same way for the majority as for the minority groups. The way in which class and ethno-generational status interact will be further investigated below.

To further explore the interrelations between class, ethnicity and generational status on educational attainment, we turn to the regression results. With regard to ethnic effects, as shown in Figure 3, the data points for most ethno-generational groups are clearly above the horizontal line denoting distance in degree-level attainment compared to the core white British, and there are no groups having lower levels of attainment than the mainstream white British. For most ethnic minority groups, we see a clear net effect of 'second generation advantage' that outweighs the 'first generation selectivity' once controls are added. Moreover, there is a trend of 'regression to the mean' among different generations of white British and mixed respondents, and a somewhat similar patterning among the white Irish and white Other groups. The black Caribbean respondents, for all their generational groupings, exhibit no signs of educational advantages as do most other groups who outperformed the white British. Class is, of course, very important for children's educational attainment, but to an expected and mostly similar extent across ethno-generational groups; there were very few significant interaction effects between ethnicity and class. An examination of the AMEs for ethnicity at each level of parental class show a

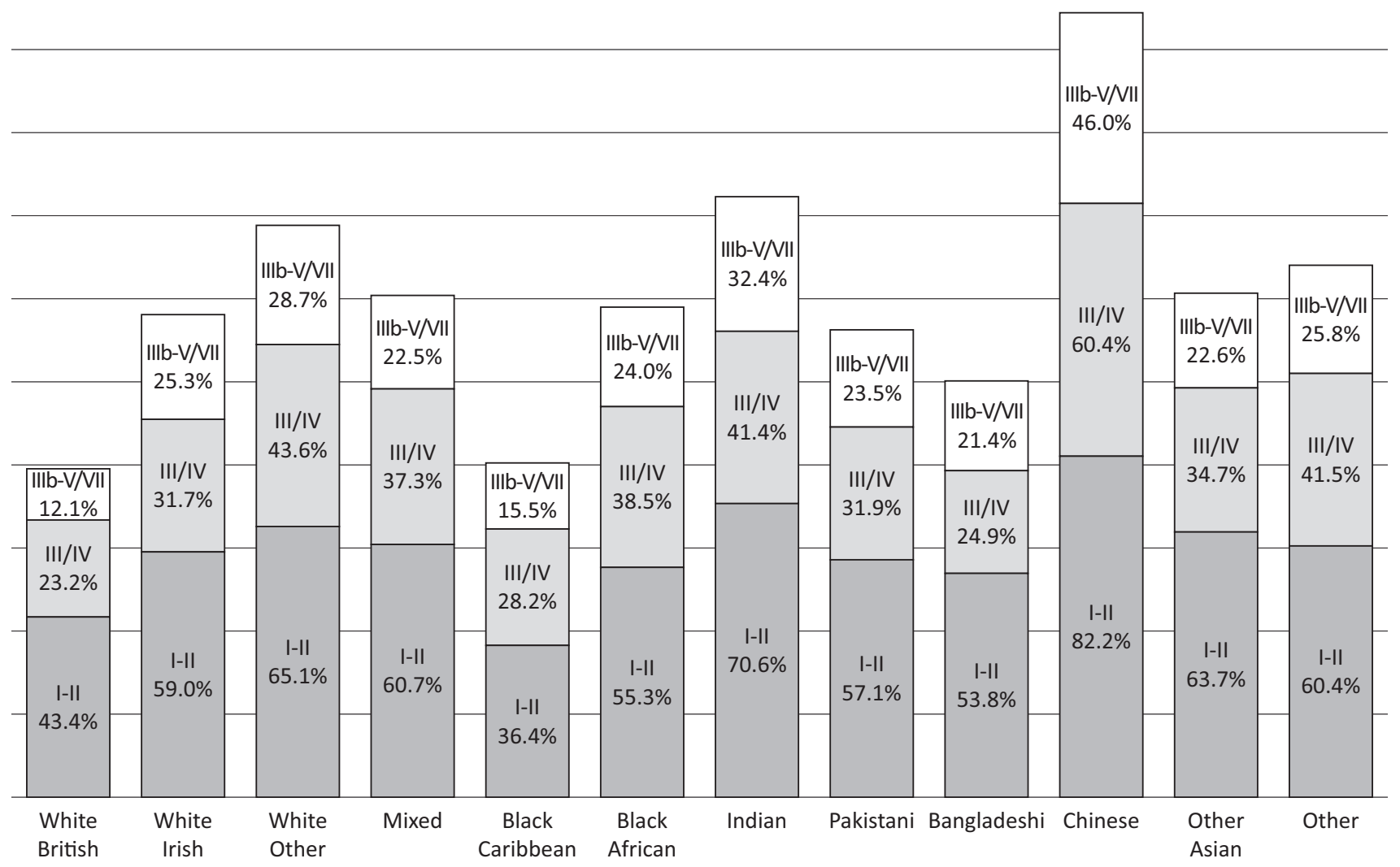

Figure 2. Degree-level attainment by ethnicity and parental social class. Source: Understanding Society. 


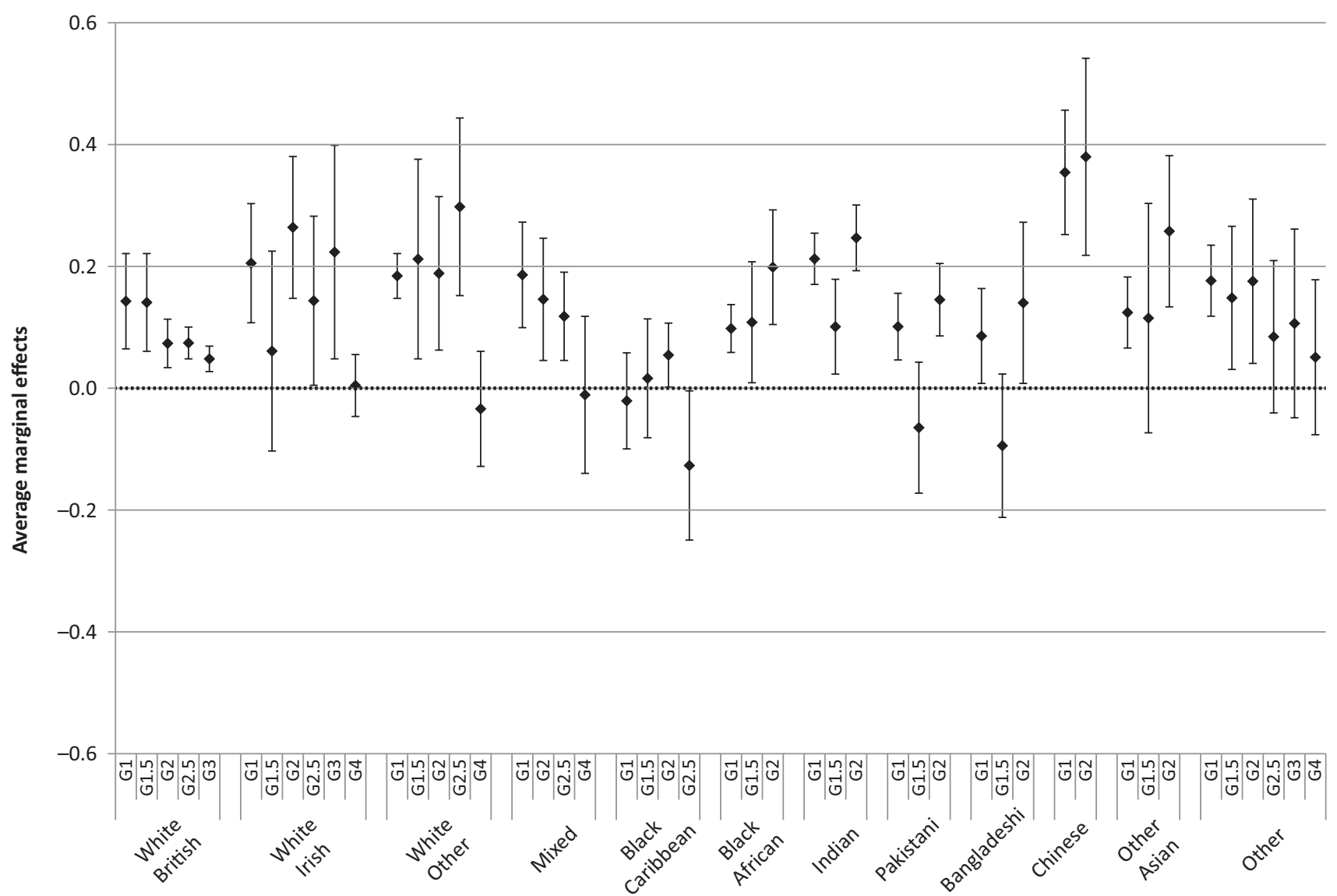

Figure 3. Average marginal effects of ethnicity on degree attainment, model controlling for class, age, and sex. Source: Understanding Society.

complex pattern of variation that generally reproduces the pattern shown above. Moreover, these results also show that the negative effects for the 2.5 generation black Caribbean respondents tend to be concentrated among the highest parental class and that 1.5 generation respondents of Pakistani (salariat) and Bangladeshi (intermediate) origins fail to achieve degree-level attainment. We have also conducted loglinear and unidiff analyses to look at the relationship between education and class for the different ethno-generational groups. The results (available on request) are largely in support of our discussion. For space reasons, we do not present the detailed modelling results here. Taken altogether, these results suggest that most ethno-generational groups seem to exhibit a greater defiance of origin effects, especially for more recent generations.

\section{Discussion and Conclusions}

With this paper, our aim was to further our understanding of the inclusion of ethno-generational groups within the UK educational structure by examining the educational attainment of ethnic groups across detailed immigrant generations. We did this by using insights from the social stratification literature and from scholarship on ethnic minorities. This was done to investigate whether the trends in the ethnic literature were supported by using more diverse measures of origin using the interaction of ethnicity and generation as a starting point for analyses. We also wanted to investigate whether the transmission of social advantage and disadvantage operates in a similar fashion for individuals with and without an immigration background. Using Understanding Society to investigate this, we were able to look at the educational attainments of 48 different ethno-generational groups.

Our results suggest four main features of interest regarding to the attainments of ethno-generational groups in the UK. In the first instance, we see a clear story of high educational selectivity among the first generation for most of the groups under study, which fits established literature about the positive selection of migrants. Even for the Black Caribbean group, which exhibits levels of attainment similar to that of the $4^{\text {th }}$ generation white British, the story is still a positive one. In the second instance, and in line with established research, UK-born individuals with immigrant parentage fit overall narratives of 'immigrant advantage' present in the literature (Kao \& Tienda, 1995).

Aside from these 'success' stories in securing a place at the top of the educational structure, we also found two other important features. Firstly, we see that the 1.5 generation does not seem to build on the skills se- 
lectivity advantage of the first generation or the 'immigrant advantage' of the second generation to the same extent. When it is possible to differentiate them from the $1^{\text {st }}$ generation, we see that members of the 1.5 generation seem to experience some type of disruptive process of migration during the school-age years for their overall educational attainment. We suggested family financial disadvantage as a reason for their decision to enter the labour market rather than stay on in education, which is plausible but needs further corroboration. This is beyond the scope of this paper, requiring detailed data on both parents' and respondents' work-life histories and family financial conditions. Finally, for the more 'established' generations, we notice an overall convergence toward the level of attainment of the more established group, the $4^{\text {th }}$ generation white British (or, in certain instances, lower levels of attainments relative to the comparison group). This also appears to be the case for individuals with some immigrant parentage, suggesting that having a non-immigrant parent may lead to convergence toward the mean rather than greater advantage. This supports the argument that, whenever possible, the 2.5 generation should be analysed separately, although for different reasons than those argued by Ramakrishnan (2004). Given that these groups tend to be relatively young, we will need to wait more time before we can say for certain whether this convergence is a trend or a demographic artefact. Moreover, more detailed analyses are needed to really disentangle the extent to which these ethnogenerational effects add to the existing, separate, advantages and disadvantages of ethnicity and generation.

Overall, we see a complicated story of social advantage and disadvantage that highlights the need to take the diversity of ethnic, immigrant, and social background into account when looking into issues of educational attainments. This has mostly been ignored but tells interesting stories with regard to the inclusion of ethno-generational groups in the UK. This suggests that parental social background may work in varying ways within groups, as recently argued by Lenkeit and colleagues (2015) and that other influences may be at play. This approach may, we believe, be useful to study inclusion into other spheres, such as the labour market where we know important disadvantages exist.

\section{Acknowledgments}

We thank the ESRC (RES-163-25-0003; ES/I035168/1; $\mathrm{ES} / \mathrm{J020036/1;} \mathrm{ES/K009206/1-2)} \mathrm{for} \mathrm{funding} \mathrm{this} \mathrm{re-}$ search. We also thank attendants at the various conferences (ECSR/EQUALSOC, Stockholm, 2012; RC28, Trento, 2013; LIVEDIFFERENCE, Sheffield 2014) and the anonymous reviewers for very helpful comments and suggestions. Data visualization was aided by Daniel's XL Toolbox addin for Excel, version 7.1.4, by Daniel Kraus, Würzburg, Germany (www.xltoolbox.net). Both authors contributed equally to the paper. We are alone responsible for any errors in this paper.

\section{Conflict of Interests}

The authors declare no conflict of interests.

\section{References}

Alba, R., Lutz, A., \& Vesselinov, E. (2001). How enduring were the inequalities among European immigrant groups in the United States? Demography, 38(3), 349-356.

Alba, R., \& Nee, V. (2003). Remaking the American mainstream: Assimilation and contemporary immigration. Harvard University Press.

Becker, G. S. (1962). Investment in human capital: A theoretical analysis. The Journal of Political Economy, 9-49.

Bhattacharyya, G., Ison, L., \& Blair, M. (2003). Minority ethnic attainment and participation in education and training: The evidence. Nottingham: DfES Publications.

Blau, P. M., \& Duncan, O. D. (1967). The American occupational structure. New York: Wiley.

Borjas, G. J. (1987). Self-selection and the earnings of immigrants. The American Economic Review, 77(4), 531-553.

Bourdieu, P. (1986). The forms of capital. In J. G. Richardson (Ed.), Handbook of theory and research for the sociology of education (pp. 241-258). New York: Greenwood Publishing Group.

Breen, R., \& Goldthorpe, J. H. (1999). Class inequality and meritocracy: A critique of Saunders and an alternative analysis. The British Journal of Sociology, 50(1), 1-27.

Breen, R., \& Jonsson, J. O. (2005). Inequality of opportunity in comparative perspective: Recent research on educational attainment and social mobility. Annual Review of Sociology, 31, 223-243.

Breen, R., Luijkx, R., Müller, W., \& Pollak, R. (2009). Nonpersistent inequality in educational attainment: Evidence from eight European countries. American Journal of Sociology, 114(5), 1475-1521.

Bukodi, E., Erikson, R., \& Goldthorpe, J. H. (2014). The effects of social origins and cognitive ability on educational attainment Evidence from Britain and Sweden. Acta Sociologica. doi:10.1177/0001699314543803

Cabinet Office. (2011). Opening doors, breaking barriers: A strategy for social mobility. London: HMSO.

Casey, L. (2016). The Casey Review: A review into opportunity and integration. London: Department for Communities and Local Government.

Castles, S., \& Miller, P. M. J. (2009). The age of migration: International population movements in the modern world (4th ed.). Cambridge: Palgrave Macmillan.

Cheng, Y. (1994). Education and class: Chinese in Britain and the United States. Aldershot: Avebury.

Cheung, S. Y., \& Heath, A. F. (2007). Nice work if you can get it: Ethnic penalties in Great Britain. In A. F. Heath \& S. Y. Cheung (Eds.), Unequal chances: Ethnic minori- 
ties in Western labour markets (pp. 507-550). Oxford: Oxford University Press.

Civil Service. (2016). Talent Action Plan 2016: Removing the barriers to success. London: HMSO.

Coleman, J. S. (1988). Social capital in the creation of human capital. American Journal of Sociology, 94, S95-S120.

Connor, H., Tyers, C., Modood, T., \& Hillage, J. (2004). Why the difference? A closer look at higher education minority ethnic students and graduates. Nottingham: DfES Publications. Retrieved from http:// www.bristol.ac.uk/ethnicity/documents/educationre port.pdf

Dale, A., Shaheen, N., Kalra, V., \& Fieldhouse, E. (2002). Routes into education and employment for young Pakistani and Bangladeshi women in the UK. Ethnic and Racial Studies, 25(6), 942-968.

Demack, S., Drew, D., \& Grimsley, M. (2000). Minding the gap: Ethnic, gender and social class differences in attainment at 16, 1988-95. Race Ethnicity and Education, 3(2), 117-143.

Department for Communities and Local Government. (2012). Creating the conditions for integration. London: Department for Communities and Local Government.

Department for Work and Pensions. (2012). Social justice: Transforming lives. London: HMSO.

Devine, F., \& Li, Y. (2013). The changing relationship between origins, education and destinations in the 1990s and 2000s. British Journal of Sociology of Education, 34(5-6), 766-791.

DiMaggio, P. (1982). Cultural capital and school success: The impact of status culture participation on the grades of US high school students. American Sociological Review, 47(2), 189-201.

Drew, D., Gray, J., \& Sporton, D. (1997). Ethnic differences in the educational participation of 16-19 yearolds. In V. Kam (Ed.), Ethnicity in the 1991 Census (Vol. 4, pp. 17-28). London: The Stationary Office.

Dustmann, C., \& Theodoropoulos, N. (2010). Ethnic minority immigrants and their children in Britain. Oxford Economic Papers, 62(2), 209-233.

Garratt, D., \& Li, Y. (2005). The foundations of experimental/empirical research methods. In B. Somekh \& C. Lewin (Eds), Research methods in the social sciences (pp. 198-206). London: Sage.

Goldthorpe, J. H. (2010). Analysing social inequality: A critique of two recent contributions from economics and epidemiology. European Sociological Review, 26(6), 731-744.

Gordon, M. M. (1964). Assimilation in American life: The role of race, religion, and national origins. New York: Oxford University Press.

Halsey, A. H., Heath, A. F., \& Ridge, J. M. (1980). Origins and destinations. Oxford: Clarendon Press.

Heath, A. F., \& Li, Y. (2008). Period, life-cycle and generational effects on ethnic minority success in the British labour market. Kölner Zeitschrift fur Soziologie und Sozialpsychologie, 48, 277-306.
Heath, A. F., \& McMahon, D. (1997). Education and occupational attainments: The impact of ethnic origins. In V. Kam (Ed.), Ethnicity in the 1991 Census (Vol. 4, pp. 97-113). London: The Stationary Office.

Heath, A. F., Rothon, C., \& Kilpi, E. (2008). The second generation in Western Europe: Education, unemployment, and occupational attainment. Annual Review of Sociology, 34(1), 211-235.

Hepburn, E. (2015). Immigrant integration and policy divergence in Scotland since devolution. Presented at the Political Studies Association, Sheffield.

Jackson, M. (2012). Bold choices: How ethnic inequalities in educational attainment are suppressed. Oxford Review of Education, 38(2), 189-208.

Kao, G., \& Tienda, M. (1995). Optimism and achievement: The educational performance of immigrant youth. Social Science Quarterly, 76, 1-19.

Lenkeit, J., Caro, D. H., \& Strand, S. (2015). Tackling the remaining attainment gap between students with and without immigrant background: An investigation into the equivalence of SES constructs. Educational Research and Evaluation, 21(1), 60-83.

Lessard-Phillips, L., Fleischmann, F., \& van Elsas, E. (2014). Ethnic minorities in ten Western countries: Migration flows, policies and institutional differences. In Unequal Attainments: Ethnic Educational Inequalities in Ten Western Countries (pp. 25-61). Oxford: Oxford University Press.

Lessard-Phillips, L., Galandini, S., de Valk, H., \& Fibbi, R. (2015). Damned if you do, damned if you don't: The challenges of including and comparing the children of immigrants in European survey data (NIDI Working Paper no.: 2015/01). The Hague: NIDI. Retrieved from http://www.nidi.nl/shared/content/ output/papers/nidi-wp-2015-01.pdf

$\mathrm{Li}, \mathrm{Y}$. (2010). The labour market situation of minority ethnic groups in Britain and the US. EurAmerica: A Journal of European and American Studies, 402, 1-51.

Li, Y., \& Heath, A. F. (2016). Class matters: A study of minority and majority social mobility in Britain, 19822011. American Journal of Sociology, 122(1), 162-200.

Lievesley, N. (2010). The future ageing of the ethnic minority population of England and Wales (Older BME People and Financial Inclusion Report). London: Runnymede Trust/Centre for Policy on Ageing.

Mood, C. (2010). Logistic regression: Why we cannot do what we think we can do, and what we can do about it. European Sociological Review, 26(1), 67-82.

Office for National Statistics. (2012). 2011 Census: Key statistics for England and Wales, March 2011. London: ONS.

Park, R. E., \& Burgess, E. W. (1921). Introduction to the science of sociology. Chicago: The University of Chicago Press.

Paterson, L., \& lannelli, C. (2007). Social class and educational attainment: A comparative study of England, Wales, and Scotland. Sociology of Education, 80(4), 330-358. 
Platt, L. (2016). Class, capital, and social mobility. In H. Dean \& L. Platt (Eds.), Social advantage and disadvantage (pp. 62-84). Oxford: Oxford University Press.

Portes, P. A., Fernández-Kelly, P. P., \& Haller, D. W. (2009). The adaptation of the immigrant second generation in America: A theoretical overview and recent evidence. Journal of Ethnic and Migration Studies, 35(7), 1077-1104.

Ramakrishnan, S. K. (2004). Second-generation immigrants? The " 2.5 Generation" in the United States. Social Science Quarterly, 85(2), 380-399.

Rees, P., Wohland, P., Norman, P., \& Boden, P. (2012). Ethnic population projections for the UK, 2001-2051. Journal of Population Research, 29(1), 45-89.

Rothon, C. (2007). Can achievement differentials be explained by social class alone? An examination of minority ethnic educational performance in England and Wales at the end of compulsory schooling. Ethnicities, 7(3), 306-322.

Rothon, C., Heath, A., \& Lessard-Phillips, L. (2009). The educational attainments of the "second generation": A comparative study of Britain, Canada, and the United States. The Teachers College Record, 111(6), 1404-1443.
Sewell, W. H., Haller, A. O., \& Portes, A. (1969). The educational and early occupational attainment process. American Sociological Review, 34, 82-92.

Simpson, L., Warren, J., \& Jivraj, S. (2015). Do people change their ethnicity over time? In Ethnic identity and inequalities in Britain: The dynamics of diversity (pp. 79-92). Bristol: Policy Press.

Strand, S. (2014). Ethnicity, gender, social class and achievement gaps at age 16: Intersectionality and "Getting it" for the white working class. Research Papers in Education, 29(2), 131-171.

University of Essex, Institute for Social and Economic Research, \& National Centre for Social Research. (2013). Understanding Society: Waves 1-3, 2009-2012 [computer file]. 5th Edition. SN: 6614. UK Data Archive [distributor].

Waters, M. C., Tran, V. C., Kasinitz, P., \& Mollenkopf, J. H. (2010). Segmented assimilation revisited: Types of acculturation and socioeconomic mobility in young adulthood. Ethnic and Racial Studies, 33(7), 1168-1193.

Zuccotti, C.V. (2015). Do parents matter? Revisiting ethnic penalties in occupation among second generation ethnic minorities in England and Wales. Sociology, 49, 229-251.

\section{About the Authors}

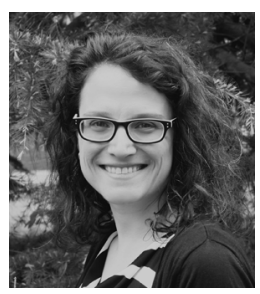

Laurence Lessard-Phillips is a Research Fellow at the Institute for Research into Superdiversity (IriS) at the University of Birmingham. Her main research interests lie in the perceptions, measurement, and dimensionality of immigrant adaptation; family influences on socio-economic and civic-political inclusion; ethnic inequalities in education and the labour market; the transnational behaviour across immigrant generations; and social inequalities and social mobility.

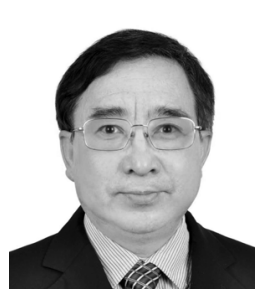

Yaojun Li is Professor of Sociology at the Department of Sociology and the Cathie Marsh Institute for Social Research, Manchester University, UK. His research interests are in social mobility and social stratification, social capital, and the socio-economic integration of ethnic minority groups. He has published widely in these areas, including papers in top sociology journals in Europe and the USA. He has also conducted numerous research projects funded by academic and government agencies in Britain, China, USA, Australia and Qatar. 